\title{
A EXCEÇÃO E A REGRA: FRAGMENTOS DE UMA REFLEXÃO JURÍDICO-LITERÁRIA
}

\author{
IARA PEREIRA RIBEIRO ${ }^{1}$
}

\begin{abstract}
RESUMO: Este estudo propõe-se à análise do texto teatral $A$ exceção $e$ a regra, escrito em 1929/1930 pelo dramaturgo alemão Bertolt Brecht. A peça trata do julgamento de um comerciante rico que, durante uma viagem de negócios pelo deserto, matou o homem que lhe servia de carregador e guia. $\mathrm{O}$ texto escolhido permite abordar a semelhança entre encenação e julgamento, tendo em vista ambos se caracterizarem pela oralidade e pela publicidade; constatar a atualidade do tema e a coincidência entre ficção e realidade; e realizar a crítica da inversão lógica do uso da regra e da exceção, que faz da exceção, a regra.
\end{abstract}

Palavras-chaves: direito e teatro; interpretação; decisão judicial.

\section{INTRODUÇÃO}

O leitor de um texto literário é levado a meditar sobre os mais variados assuntos. Se o leitor for um estudioso do Direito, ao construir a sua compreensão do texto, vale-se muito do seu conhecimento técnico, da sua vivência profissional. Por outro lado, a leitura da obra literária permite que esse mesmo leitor conheça novos pontos de vista. A comunicação desses dois saberes é enriquecedora, principalmente quando realizada de modo consciente.

O objetivo desse artigo é evidenciar como esse diálogo entre Direito e Literatura acontece. Para tanto, utilizaremos a peça teatral $A$ exceção e a regra, escrita em 1929/1930 pelo dramaturgo alemão Bertolt Brecht (1990).

\footnotetext{
1 Doutora em Direito (PUC/SP). Professora do Departamento de Direito Privado da Faculdade de Direito de Ribeirão Preto da Universidade de São Paulo. E-mail: iararibeiro@usp.br
} 
Essa abordagem jurídico-literária do texto pode ocorrer de distintas formas, todas interessantes e relevantes. De tal modo que há certa dificuldade metodológica, detectada por Silva (2009, p. 66), de precisar as fronteiras entre o direito na literatura e o direito como literatura ${ }^{2}$.

$\mathrm{Na}$ análise da peça, a aproximação mais evidente de Direito e Literatura se dá pelo denominado "direito na literatura". Trata-se do julgamento de um comerciante que assassinou seu empregado3. Conhecer as circunstâncias do crime, as ambiguidades das personagens, as situações conflituosas vivenciadas por eles permite, pela narrativa literária, tangenciar uma experiência não vivida que possibilita ao leitor/jurista refletir sobre as próprias vivências profissionais, ou não4.

Porém, uma decisão judicial polêmica proferida pelo Tribunal de Justiça de São Paulo e divulgada pela imprensa indicou outra abordagem do texto, que pode ser classificada de "direito como literatura". A narrativa do acórdão assemelha-se à narrativa da peça, e o desembargador constrói sua decisão nas mesmas bases dos juízes de Brecht.

A obra literária $A$ exceção e a regra desperta interesse também por outra razão. A leitura do texto auxilia à compreensão do Direito por outra via que não a normativa. Assim, da reflexão crítica do texto, chega-se ao Direito. A utilização pedagógica da Literatura no ensino do Direito resulta da constatação de que o fenômeno jurídico existe no cotidiano e sob ele incidem elementos extrajurídicos, que devem ser levados em conta para a compreensão do próprio fenômeno (Silva, 2009, p. 129).

Como os caminhos apontados não são excludentes e, muito ao contrário, podem ser complementares, optamos por discorrer sobre as várias possibilidades de aproximação entre Direito e Literatura que o texto nos permitiu alcançar. Sem eleger apenas um caminho, adotamos uma

2 Silva (2009, p. 55) afirma, ainda, que a classificação em Direito na ou como Literatura é demasiado estreita e acadêmica, destacando que o amadurecimento dos estudos jurídicoliterários tornou difícil manter a pureza dessa distinção.

3 Como se verá no decorrer do texto, ele não é exatamente "empregado" na acepção jurídica da palavra. É um trabalhador não sindicalizado e, nas circunstâncias histórica e territorial do texto, desprovido de qualquer proteção trabalhista.

4 Silva alerta que a leitura de obras literárias não torna o indivíduo moralmente melhor, talvez, apenas mais compreensivo e preparado para lidar com a diferença, mais propenso a uma identificação empática com o outro (2009, p. 59). 
abordagem fragmentada para evidenciar alguns aspectos de interesse jurídico-literário do texto de Brecht.

\section{O ENREDO}

A peça trata do julgamento de um homicídio ocorrido durante uma viagem pelo deserto, realizada por um comerciante, um guia e um carregador (cule).

O objetivo da viagem é chegar antes dos concorrentes do comerciante à cidade de Urga, para realização de um negócio de concessão de exploração de petróleo ${ }^{5}$. No decorrer da dura e cansativa viagem, o comerciante reflete sobre as diferenças sociais que existem entre eles. Consciente de sua desvantagem numérica e com receio de que os dois se unissem contra ele, demite o guia, continuando a viagem apenas com o carregador, homem mais simples, menos instruído e desprotegido pela lei.

A estratégia de seguir viagem apenas com o carregador mostrou-se desastrosa, visto que a ausência do guia não eliminou as desconfianças do comerciante, pelo contrário, produziu outras situações conflituosas e como ambos não conheciam o caminho andaram em círculos até acabarem perdidos no deserto, praticamente sem água. O clímax da viagem ocorre quando o carregador, que a conselho do guia despedido havia guardado consigo um cantil reserva, resolve oferecê-lo ao comerciante, pois sabia que poderia ser acusado se o outro morresse de sede. Com esse pensamento, levanta-se e no escuro dirige-se ao comerciante com o cantil na mão. Este, por sua vez, tendo adotado a mesma estratégia de esconder um cantil reserva, ao ser surpreendido pelo carregador, pensa que foi flagrado bebendo água. Assustado, atira e mata o carregador.

5 Embora seja esse o objetivo afirmado pelo comerciante, em outro momento do texto fica explícito que a sua real intenção que não é a do desenvolvimento, mas a do segredo, para que tudo se mantenha do mesmo jeito:

"CULE: O comerciante sempre diz que tirar petróleo da terra é um serviço que se presta à humanidade: quando o petróleo é tirado da terra, abrem-se estradas e o bem-estar é geral. Diz o comerciante que até aqui vai ter estrada-de-ferro. E eu, então, como é que vou ganhar a vida?

GUIA: Pode ficar descansado. Não vai haver estrada aqui tão cedo! Ouvi dizer que o petróleo, se uma pessoa descobre, logo aparece outra e esconde: quem tapa um furo de onde sai petróleo, recebe um dinheirão para guardar segredo. E é por isto que o nosso comerciante está com tanta pressa: o que ele quer mesmo não é o petróleo, é o dinheiro para guardar segredo!

CULE: Não compreendo.

GUIA: Ninguém compreende.” (Brecht, 1990, p. 136-137). 
A cena do julgamento é o ponto central da peça. Na sessão em que o comerciante será julgado pela morte do carregador, estão presentes três juízes, o comerciante, a esposa do carregador, o guia, o estalajadeiro do albergue onde o guia foi despedido e o chefe de outra caravana, que vinha logo atrás e tinha o mesmo propósito negocial do comerciante. É nessa altura do texto que Brecht irá favorecer as elucubrações sobre a exceção e a regra.

\section{JULGAMENTO E ENCENAÇÃO}

O tema do julgamento é recorrente na literatura, mas é a encenação do texto no teatro, no cinema ou na televisão que melhor apresenta os elementos, os papéis, as funções, os interesses e as técnicas envolvidas em um julgamento. $\mathrm{O}$ encaixe quase perfeito entre tema e expressão artística, entre julgamento e encenação, direito e arte, ocorre especialmente devido a dois elementos que se fazem presentes no julgamento e na encenação: a oralidade e a publicidade.

A audiência de julgamento talvez seja o ato processual mais conhecido pela população. Os participantes da audiência devem se comunicar por meio da fala, o próprio significado da palavra audiência denota esta acepção de dar atenção a quem fala. A oralidade do ato é sua marca, distinguindo-o de outros atos que acontecem por escrito. É na audiência de julgamento que se dá a oportunidade para que os atores do Direito (advogados, promotores, juiz, oficiais, testemunhas, autor, réu, peritos etc.) se expressem verbalmente, tal qual ocorre na maioria das representações cênicas.

A possibilidade da presença de plateia na audiência é outro elemento que a faz se assemelhar a uma encenação. Os atos processuais devem ter publicidade, o que significa que, em regra, eles podem ser conhecidos e podem ser realizados na presença do público. A lei restringe a publicidade apenas em algumas hipóteses, como para defender a intimidade ou se assim o exigir o interesse social. A plateia que assiste a uma audiência de julgamento ouve os envolvidos (advogados, partes, testemunhas, juiz), acompanha a oratória, os gestos, as expressões faciais, os ruídos produzidos por um ou por outro, constrói sua própria versão dos fatos e aguarda o desfecho proferido pelo juiz. 
A presença do público nas audiências, autorizada constitucionalmente ${ }^{6}$, é disciplinada no Código de Processo Penal, que impõe ao espectador um comportamento apropriado, podendo ser retirado da sala de julgamento e eventualmente até ser preso, se agir de modo inadequado7. O público participa da audiência, tal como participa de uma encenação teatral, cinematográfica ou televisiva, e, mesmo que de forma contida, se emociona, torce, indigna-se, comenta ${ }^{8}$.

A aproximação do julgamento com a encenação artística não se restringe à oralidade e à publicidade. Nota-se que a audiência se dá em um espaço determinado, com objetos como mesa e cadeiras posicionadas de forma ordenada, um vestuário apropriado ${ }^{9}$ e lugares marcados ${ }^{10}$. Muito semelhante com o que acontece em uma representação cênica: palco, cenário, figurino e marcação de atores.

Certamente que a composição da sala de audiência de julgamento e a do cenário para a representação cênica possuem propósitos distintos: no cenário, o objetivo é compor um ambiente para auxiliar o público a compreender a representação; já o ambiente das salas de audiência parece, à primeira vista, que objetiva ser funcional, no sentido de servir bem aos profissionais que ali trabalham, contudo a disposição dos móveis e objetos está carregada de significados que transmitem a ideia de poder (Canetti, 1995, p. 389-390; Foucault, 1996, p. 45).

${ }^{6}$ Art. $5^{\mathrm{o}}$, LX, da CF: "a lei só poderá restringir a publicidade dos atos processuais quando a defesa da intimidade ou o interesse social o exigirem;".

7 Art. 795, CPP: "Os espectadores das audiências ou das sessões não poderão manifestar-se. Parágrafo único: O juiz ou o presidente fará retirar da sala os desobedientes, que, em caso de resistência, serão presos e autuados".

${ }^{8}$ Francesco Carnelutti crítica o interesse do público pelos julgamentos penais. Afirma que essa diversão é uma forma de fuga da própria vida, instigada pelo ocupar-se com o drama do outro. Entende que se deliciar com um julgamento, do mesmo modo que é possível se entreter com um espetáculo cinematográfico, sem atenção ao drama real dos protagonistas é uma incivilidade, tal qual era a luta dos gladiadores ou a corrida de touros (1995, p. 12). Elias Canetti verifica que há um prazer em condenar, dizer que "um livro é ruim", logo significa "ele é um mau poeta"; a pessoa atribui a si mesma o poder do juiz de sentenciar e, ao fazê-lo, separa os bons dos maus, obviamente incluindo-se no lado dos bons (1995, p. 296-298).

9 Carnelutti escreve sobre a importância da toga usada pelos magistrados (1995, p. 17-20).

${ }^{10}$ Lenio Luiz Streck descreve a sala de julgamento de um Tribunal do Júri para evidenciar que as desigualdades econômicas e culturais da sociedade podem ser percebidas por um olhar mais atento à distribuição dos móveis e objetos na sala (2001, p. 107). 


\section{A PEÇA DE BRECHT}

A história da peça "A exceção e a regra" é contada em um texto curto, dividido em nove cenas, sendo que uma das cenas consiste no canto entoado pelos atores enquanto mudam o cenário. Nessa cena, a história não se desenrola, ela existe para evidenciar ao público a passagem de tempo e o deslocamento de espaço, do deserto para o Tribunal.

O autor utiliza o recurso de despersonalizar os atores três vezes: na apresentação, na mudança de cenário (com o Canto dos Tribunais) e ao final. Nessas falas coletivas, há a provocação dirigida ao público. Logo na apresentação, aconselha e instiga a "ver bem", "estranhar, o que não parece estranho", desconfiar, "não achar natural o que acontece, e torna acontecer". Na fala final, incita o público a agir: "a vocês nos pedimos [...] onde o abuso apontar, procurem remediar!". Esse ato de estimular o público a agir reflete o posicionamento político e filosófico do autor que, inserido no contexto do século $\mathrm{XX}$, entende a arte como meio de transformação da sociedade, e justifica a classificação que o próprio Brecht atribui ao texto: peça didática.

Das nove cenas, as sete primeiras se situam no deserto. Na primeira cena, o público (ou o leitor) conhece os protagonistas da história e é informado sobre o motivo da viagem. É o próprio comerciante que se dirige ao público e se apresenta: "Eu sou o comerciante Karl Langmann e vou de viagem para a cidade de Urga espero fechar o negócio de uma concessão" (Brecht, 1990, p. 133).

Interessante observar que o comerciante é o único personagem que possui nome, todos os outros são identificados pela profissão que exercem (guia, cule, estalajadeiro, policial, chefe da caravana e juiz).

A indicação do nome do comerciante evidencia a sua importância como pessoa. Ele é um ser único, não é mais um guia ou um carregador, ele é Karl Langmann.

A individualização da pessoa é tema da Teoria Geral do Direito Privado $^{11}$. Ter um nome é uma forma de individualização que confere à

\footnotetext{
${ }^{11}$ Ensina Rosa Maria de Andrade Nery que o que confere à pessoa o aspecto de ser única são os atributos da personalidade, como capacidade, status, nome, fama e domicílio. Esses atributos distinguem a pessoa dos demais, carregam o indivíduo de especial dignidade no contexto jurídico das relações (2002, p. 153).
} 
pessoa a possibilidade de ser sujeito de direitos e deveres (Pontes de Miranda, 2012, p. 138), porque não é possível atribuir algo a alguém sem se saber "quem". Os demais personagens, todos sem nome, não importam como pessoas dotadas de personalidade e sujeitos de direitos e obrigações.

Embora o direito a ter um nome não seja expressamente previsto nos incisos do Art. $5^{\circ}$ da Constituição Federal que tratam dos direitos e garantias fundamentais, não resta dúvida que é esta sua natureza, pois todas as pessoas têm direito a terem um nome ${ }^{12}$ e a serem chamadas por esse nome, independente da situação da vida em que se encontrem ${ }^{13}$. O direito a ter um nome decorre diretamente do princípio constitucional da dignidade da pessoa humana e da exegese do caput do citado artigo, que dispõe serem todos iguais perante a lei, sem distinção de qualquer natureza. Não há distinção maior que ser inominado.

O autor, ao não identificar os demais personagens, coloca-os como uma massa despersonalizada. Evidentemente, a despersonalização da pessoa natural não é admitida em um Estado Democrático de Direito, porém é uma alegoria de provocação comum nas manifestações artísticas ${ }^{14}$.

É interessante apontar que apenas um dos personagens é mulher. Como todos os outros personagens, ela igualmente não possui nome. Sua identificação, porém, não decorre de sua profissão ou ocupação, mas de seu

\footnotetext{
${ }^{12}$ Direito a ter um nome é diferente de direito ao nome. No primeiro caso, temos que se trata de direito fundamental implícito (sobre o tema, ver Sarlet, 2011, p. 84-91), enquanto que direito ao nome é direito da personalidade, disposto no Art. 16 do Código Civil de 2002: "Toda pessoa tem direito ao nome, nele compreendidos o prenome e o sobrenome".

13 Por exemplo, a Lei de Execução Penal (Lei n ${ }^{0}$ 7.210/984) dispõe no "Art. 41 - Constituem direitos do preso: XI - chamamento nominal”. No mesmo sentido, a Resolução $n^{\circ} 14$, de 11 nov. 1994, do Conselho Nacional de Política Criminal e Penitenciária, que fixa as regras mínimas para o tratamento do preso no Brasil: "Art. $4^{\circ}$. O preso terá o direito de ser chamado por seu nome".

${ }^{14}$ Entre vários exemplos possíveis, apontamos os versos da canção Admirável gado novo, do músico e compositor Zé Ramalho, que a nosso ver também dialogam com o texto de Brecht:

Vocês que fazem parte dessa massa

Que passa nos projeto do futuro

E duro tanto ter que caminhar

$\mathrm{E}$ dar muito mais do que receber

E ter que demonstra sua coragem

À margem do que possa parecer

E ver que toda essa engrenagem

Já sente a ferrugem lhe comer.
} 
status $^{15}$, é simplesmente a "mulher do cule". Essa designação de "mulher do cule”, para o Direito, qualifica o personagem pelo seu status familiae: ela, por ser a esposa, por possuir esse status, é aquela que está autorizada a reclamar em juízo ressarcimento material pela morte do marido. $\mathrm{Na}$ interpretação do texto, porém, nos parece que a designação de "mulher do cule” indica a sua pouca importância social, já que o cule (o carregador) não tem nome, não é individualizado, ora ser a "mulher" de nada, é nada.

O desfecho da peça ocorre na cena do julgamento no Tribunal, momento em que o Comerciante, agora Réu, é ouvido e julgado.

Na sala de julgamento, encontram-se a mulher da vítima, o guia, o estalajadeiro, os membros da segunda caravana, o comerciante e os juízes. Nota-se que há na cena a presença das figuras do juiz, do réu, das testemunhas, dos interessados na questão (no caso, a mulher do cule) e da plateia (composta pelos outros membros da segunda caravana que não serão ouvidos e, de forma estendida, pelo público que assiste ao espetáculo). As figuras ausentes da cena - e da peça - são a do Acusador e a do Defensor, ou seja, a do representante do Ministério Público, o Promotor de Justiça, e a do Advogado de Defesa. No que diz respeito ao aspecto cênico, a ausência desses personagens é justificável, pois a presença de três juízes transmite mais intensamente a ideia de poder, ao passo que o uso cênico dos três papéis (juiz, promotor e advogado) realçaria a ideia do debate, da retórica, que não parece ser o interesse do autor neste texto. Sem esses personagens, as falas possíveis para defender ou acusar são ditas pelos próprios juízes, como se verifica nos seguintes trechos:

JUIZ ao guia: Assim, tinha de engolir muita coisa, não é? Responda! Não fique aí pensando o tempo todo em cada resposta que tem a dar! A verdade sempre vem à tona. (Brecht, 1990, p. 153);

JUIZ (aconselhando o réu): Ouça: o senhor não deve fazer-se de mais inocente do que é. Assim não vai dar em nada, homem. [...] É só tornando esse ódio justificável, que o senhor poderá justificar também que agiu em legítima defesa. Pense bem! (Brecht, 1990, p. 154);

\footnotetext{
${ }^{15}$ O status (estado) é atributo da personalidade, que traduz a qualificação jurídica da pessoa no grupo social em que ela está inserida, seja no âmbito individual, familiar ou político.
} 
PRIMEIRO JUIZ ADJUNTO: Isto é um cantil com água, não é pedra nenhuma: ele ia oferecer água ao senhor! (Brecht, 1990, p. 156);

SEGUNDO JUIZ ADJUNTO: Agora, tudo indica que ele não pretendia em absoluto matar ninguém. (Brecht, 1990, p. 156);

JUIZ: Como pode ser isso? Ao comerciante: - Ele ia dar de beber ao senhor! (Brecht, 1990, p. 157);

JUIZ: Não era pedra nenhuma: não está vendo que é um cantil com água? (Brecht, 1990, p. 157).

O recurso de unir na figura dos juízes as três funções - de acusador, de defensor e de julgador - esconde do leitor e do público o desfecho. Até a última fala, não se pode inferir qual será o resultado do julgamento. O que é muito interessante para uma peça de teatro, mantendo o interesse do ouvinte por todo o tempo.

Por outro lado, na análise discursiva do texto, parece-nos que a união das três funções numa única figura evidencia a igualdade de origem, dos olhares, de valores compartilhados por aqueles que exercem função judiciária. Os advogados, os promotores e os juízes, mesmo exercendo funções distintas, assemelham-se quando reproduzem autonomamente os desvios, as inverdades, as contradições do sistema no qual estão inseridos.

Essa semelhança dos discursos da acusação e da defesa é sintetizada por Lenio Streck na frase "matem-se entre vós que nós os julgaremos entre nós" (2001, p. 131).

\section{A ATUALIDADE DO TEXTO DE BRECHT}

No texto, há um diálogo entre o juiz e a esposa do falecido que tangencia o tema da responsabilidade civil:

JUIZ: A senhora pede também uma indenização.

MULHER: É, porque eu e meu filho pequeno ficamos sem aquele que nos dava o sustento.

JUIZ: Eu não censuro a senhora por isso: a exigência de ordem material não constitui nenhum demérito para a senhora. (Brecht, 1990, p. 152)

A pretensão da viúva por uma indenização é aceitável pelo Tribunal, mas, antes, é justificada pela viúva e avaliada moralmente pelo juiz. A mulher do carregador praticamente se desculpa por requerê-la, seu pedido funda-se na necessidade ("ficamos sem aquele que nos dava o sustento"), e 
não em um direito. Embora, no texto, o que pretenda é um ressarcimento por dano material, o recebimento de indenização pecuniária pelo falecimento do marido é analisado moralmente: "Não a censuro", diz o juiz e continua "não constitui nenhum demérito". O diálogo evidencia o conflito punição/reparação. É esperado desejar que aquele que matou seja punido. Na peça, é de certo modo indigna a reparação econômica.

Contudo, a indenização não tem a mesma função que a condenação penal. O fundamento da pena é punir o agente por conduta contrária ao ordenamento jurídico. A indenização é uma reparação por ter causado dano ao bem jurídico de outrem (Larenz, 1985, p. 114) e não necessita sequer de prova de prejuízo econômico's ${ }^{16}$

Recentemente, uma decisão judicial do TJ-SP evidenciou a contemporaneidade do texto $A$ exceção e a regra. O Tribunal analisou o pedido de indenização por dano material e moral de Alexandro Wagner Oliveira da Silveira, repórter fotográfico que, durante cobertura jornalística de manifestação grevista na Avenida Paulista, na cidade de São Paulo, foi ferido no olho esquerdo por um projetil de borracha disparado por um policial ${ }^{17}$. O ferimento descolou sua retina, incapacitando-o parcial e permanentemente para o exercício da mesma função.

Em que pese à similitude estrutural das decisões judiciais, parece-nos que nesse acórdão há uma coincidência narrativa com o texto $A$ exceção e a regra. Primeiramente, o acontecimento é situado no tempo e no espaço: "É

${ }^{16} \mathrm{O}$ entendimento do STJ em relação ao direito à imagem encontra-se na Súmula 403: "Independe de prova do prejuízo a indenização pela publicação não autorizada de imagem de pessoa com fins econômico ou comerciais.”.

${ }^{17}$ BRASIL. Tribunal de Justiça do Estado de São Paulo. $2^{\text {a }}$ Câmara Extraordinária de Direito Público. APELAÇÕES E REEXAME NECESSÁRIO Ação de indenização Repórter fotográfico ferido em cobertura jornalística durante manifestação realizada na Avenida Paulista, Capital-SP, em movimento grevista. Boa probabilidade de que o ferimento, no olho esquerdo, do qual resultou descolamento de retina e sequela incapacitante, parcial e permanente, para exercer funções que necessitem de referência de visão normal, resultar de disparo de projétil de borracha efetuado por policial Intervenção policial justificada, ante a ilícita obstrução da via pública pelos manifestantes, que resistiram à desocupação da via, inclusive de modo agressivo Uso da força pública, de bombas de efeito moral e de disparos de projéteis de borracha necessários Ausência de elementos para se afirmar, no caso, ocorrência de abuso ou excesso na referida conduta policial atrelada ao tal disparo que feriu o autor Posição da vítima em meio ao tumulto, entre os manifestantes e os policiais, observada a sua permanência no local de conflito, para fotografar, em situação de risco ou de perigo assumido, a excluir a responsabilidade do ente público Sentença de procedência parcial da demanda reformada para de improcedência RECURSO DA RÉ E REEXAME NECESSÁRIO PROVIDOS. DESPROVIDO O RECURSO DO AUTOR. APELAÇÃO No 0108144-93.2008.8.26.0000. Voto $n^{0}$ 8.247. Relator: Juiz Vicente de Abreu Amadei, 28-8-2014. 
fato certo e bem comprovado nos autos que, no dia 18/05/2013, houve manifestação de greve nesta Capital, na Avenida Paulista, em frente ao MASP”, em seguida narra-se o confronto em detalhes: "a qual se realizava com interrupção de apenas uma das vias de direção daquela via pública, mas, em determinado momento, diversos manifestantes resolveram parar a via oposta de direção, interrompendo o tráfego de veículos deste outro lado, e, então, a tropa de choque da Polícia Militar interveio, para desobstruir aquela pista, e, assim, ocorreu o triste tumulto: de um lado, manifestantes atirando pedras, paus e coco nos policiais, e, de outro, os policiais agindo com uso de cacete, bombas de efeito moral disparos e balas de borracha." Pela descrição, é perfeitamente possível ao leitor do acórdão imaginar a cena do confronto entre manifestantes e policiais, potencializada pela frase "ocorreu o triste tumulto".

Em seguida, o leitor é apresentado à vítima (autor da ação judicial), o fotógrafo: "Certo, ainda, que o autor, que se encontrava no local, trabalhando como repórter fotográfico, em cobertura jornalística, terminou ferido por agente contundente, na região do olho esquerdo". E de forma sutil, também, toma conhecimento de que a vítima, embora fotógrafo, enxerga mal "e daí, houve hemorragia vítrea e descolamento de retina, que resultou em limitação visual (para além daquela que ele já tinha no olho direito, por causa endógena e congênita) ou baixa visão”. É importante ressaltar o fato de que a informação sobre a baixa visão do olho direito vem destacada no acórdão, com a colocação de parênteses e grafada em tipo menor do que o usado no restante do texto. Chama atenção esse destaque porque, à primeira vista, é uma informação que não importa para os autos.

A respeito da comprovação de que foi a ação policial que causou o ferimento na vítima, afirma-se que não há "plena certeza", mas que "É preciso ponderar, todavia, que, mesmo sem esta plena certeza, há elevada probabilidade para se afirmar que disparo de projétil de borracha efetuado por policial tenha sido a causa eficiente daquela lesão".

Ora, até esse ponto do acórdão, a construção narrativa leva o leitor a inferir que a ação será julgada procedente, ou seja, que o fotógrafo ferido será indenizado. Ressaltado, ainda mais, pelo seguinte trecho: “Assim, doume por convencido de ser a bala de borracha disparada por policial a causa eficiente do infortúnio". 
O mesmo efeito Brecht produz na fala do juiz: "Então eu vou proferir a sentença! O Tribunal considera provado que o carregador aproximou-se do patrão, não com uma pedra, e sim com um cantil d’água” (Brecht, 1990, p. 159).

Porém, surpreendentemente, tanto no acórdão quanto na peça, a decisão do julgamento é diferente daquela que se esperava. No acórdão, afirma-se que o fotógrafo deliberadamente "colocou-se em situação de risco ou de perigo, quiçá inerente à sua profissão" e que é "dele a culpa exclusiva do lamentável episódio do qual foi vítima”.

Na peça, o Juiz afirma: "O acusado, portanto, agiu em legítima defesa, tanto no caso de ter sido realmente ameaçado, quanto no caso de apenas sentir-se ameaçado. Isto posto, absolve-se o acusado, e não se toma conhecimento da queixa da mulher do morto" (Brecht, 1990, p. 160).

Assim, o fotógrafo e o cule (carregador), distantes pela realidade e ficção, compartilharam o mesmo destino, são culpados por seus infortúnios.

\section{O QUE É EXCEÇÃO E O QUE É REGRA?}

A peça se chama $A$ exceção e a regra. O que nos leva a indagar, o que é a exceção e o que é a regra no texto de Brecht.

Inicialmente, podemos considerar que exceção é o comportamento do carregador. O comerciante pensa o mesmo, tanto que ao descobrir, durante o julgamento, que o carregador levava nas mãos um cantil, e não uma pedra, se defende: "Mas eu nunca podia imaginar que fosse um cantil com água: aquele homem não tinha motivo algum para me dar de beber! Eu não era amigo dele" (Brecht, 1990, p. 157, grifei).

Inconformado, expõe o quanto era improvável imaginar a ação amistosa do carregador: "Só se ele era muito imbecil, mesmo. Um sujeito que, por minha causa, sofreu um acidente capaz de deixá-lo aleijado para o resto da vida, e logo num braço! Nada mais justo, da parte dele, do que querer ir à forra” (Brecht, 1990, p. 157, grifei).

Por fim, conclui, justificando seu ato e acusando a vítima: "Admitir que o carregador não quisesse acabar comigo na primeira oportunidade, seria admitir que ele não tivesse nenhum bom-senso" (Brecht, 1990, p. 158, grifei). 
O juiz apresenta o mesmo estranhamento em relação ao comportamento do carregador, perguntando "Por que iria dar água ao patrão? Por quê?”. É o guia quem responde:

Deve ter imaginado que o comerciante estava com sede. Os juízes sorriem uns para os outros. Decerto por um sentimento de humanidade. Os juízes tornam a sorrir. Talvez até por imbecilidade, e por isso eu acho que ele não tinha nada contra o comerciante (Brecht, 1990, p. 157).

Na visão do comerciante e dos juízes, a ação de dar água a quem tem sede não é uma ação esperada, principalmente se aquele a quem se oferta é mais rico e mais poderoso. O esperado é o contrário, quem tem mais deve sempre guardar distância e desconfiança de quem não tem. O comerciante age, portanto, conforme a regra. Nessa lógica, a absolvição do comerciante se justifica, uma vez que ele agiu como qualquer um agiria nas mesmas circunstâncias.

Porém, esse desfecho dado por Brecht é desconfortável, tendo em vista que o ato de oferecer água a quem tem sede não pode jamais ser considerado uma exceção. Ora, essa deve ser a regra.

Não importam os motivos do carregador para oferecer a água. Se o fez por humanidade ou por receio de ser punido se o comerciante morresse de sede, não desqualifica a sua ação. Assim como não altera o fato de que ele não ameaçou o comerciante.

Pela perspectiva jurídica, o título $A$ exceção e a regra suscita outras considerações. O comerciante responde judicialmente por homicídio, conduta tipificada no Art. 121 do Código Penal Brasileiro ${ }^{18}$. Quando é sentenciado, sua absolvição é fundamentada na permissão legal para matar do Art. 23 do mesmo Código Penal ${ }^{19}$. Ou seja, a lei prevê as duas condutas, a de que é proibido matar e a de que é permitido matar em legítima defesa.

É interessante refletir sobre o que significa a exceção no âmbito do Direito. De pronto, afastamos o conceito jurídico de exceção como todo tipo de defesa das partes no processo judicial. O conceito de exceção que interessa nesse estudo é o de "derrogação de um princípio ou uma regra, em virtude da qual se isenta o ato ou pessoa da obrigação ou imposição nela

${ }_{18}$ Art. 121, CP: "Matar alguém: Pena - reclusão, de seis a vinte anos”.

${ }^{19}$ Art. 23, CP: "Não há crime quando o agente pratica o fato: II - em legítima defesa". 
contida" (De Plácido e Silva, 2004, p. 570). Assim, regra é o preceito geral, e exceção é o preceito especial que exclui a aplicação do geral.

Emilio Betti, ao tratar de normas excepcionais, expõe que elas se caracterizam por colidirem com os princípios fundamentais da ordem jurídica a que pertencem. Explica que cabe apenas e tão somente ao Estado a tutela jurisdicional dos direitos, e só por exceção admite-se que os indivíduos se utilizem da autotutela privada, como, por exemplo, a defesa da posse. Esses princípios fundamentais trazem normalidade a essa ordem jurídica e lhe conferem uma coerência racional, para que seja elaborada num sistema como uma totalidade orgânica (2007, p. 112; 114).

No sistema jurídico brasileiro - por mais que nos noticiários pareça ser o contrário -, "não matar" é uma regra. O enunciado do Art. 121 do Código Penal, embora seja descritivo de uma conduta, deduz a proposição proibitiva de "não matar". A Constituição Federal de 1988, no Art. 5º, XLVII, proíbe a pena de morte, salvo em caso de guerra - que por si só é uma exceção. Também não é admitido, em regra, o aborto, a eutanásia ou outras formas de degradação e eliminação da vida. O sistema jurídico brasileiro não concebe o domínio da vida ${ }^{20}$.

Logo, a legítima defesa é uma exceção à regra, pois é uma autodefesa autorizada pelo Estado, diante de uma agressão injusta, que pode resultar até na morte do agressor (Toledo, 1991, p. 192).

Pensamos que a exceção é um mecanismo criado pelo sistema jurídico para se preservar, uma vez que possibilita a realização efetiva de justiça ${ }^{21}$. Pode-se dizer que o homem que mata em legítima defesa não é um assassino. Será? Não é um criminoso, mas será um assassino, visto que matou um homem, mesmo que seu ato seja justificado pela defesa de sua própria vida. A exceção surge como um modo de subverter o preceito geral,

\footnotetext{
${ }^{20}$ A expressão é de Ronald Dworkin.

${ }^{21}$ Afirma Norbert Horn ser a questão da justiça uma indagação permanente, quando destaca que "Toda reflexão a respeito do Direito é acompanhada da questão sobre se nós podemos nos orientar por mandamentos de justiça os quais já existam antes da lei e independentemente de qualquer legislação (pré-positivos), para os quais tanto o legislador quanto o jurista aplicador do Direito devem atentar, porque estes mandamentos são «indisponíveis»". E, na sequência, afirma: "Cada época deve prestar contas a respeito de como trata essa questão e que lugar lhe concede dentro e fora da aplicação do Direito e da ciência. Em todos os tempos, a questão da justiça foi acompanhada pela dúvida de se, e de que maneira, pode-se encontrar respostas seguras neste âmbito”. (2005, p.343-344).
} 
no qual o suporte fático da norma jurídica permite a não aplicação de uma sanção e absolve um assassino.

Entendemos que é tarefa interpretativa do Jurista - não apenas do juiz, pois, se a ele cabe decidir, a todos cabe compreender o Direito identificar a regra, reconhecer qual lei geral e abstrata é aplicável ao caso, notar quais circunstâncias fáticas determinam sua aplicação e, depois, verificar se há previsão legal de exceções que abrigam os fatos ocorridos. Há inadequação quando se dá à exceção o caráter de regra ou se aplica a regra sem sequer verificar a possibilidade de exceções. Na primeira hipótese, quando se faz da exceção uma regra, tem-se o entendimento de que há injustiça, já que o preceito de caráter especial altera-se para beneficiar determinado grupo de pessoas, mitigando os efeitos do preceito geral, daí decorre a percepção de que a lei não é para todos, mas só para alguns. Por outro lado, a cegueira na aplicação do preceito geral indica abuso ao não se observarem os preceitos especiais. Diz Bertolt Brecht:

\author{
Na regra vejam o abuso! \\ E, onde o abuso apontar, \\ Procurem remediar! (Brecht, 1990, p. 160).
}

Retomando a análise dos artigos 121 e 23, II, do Código Penal, entre as duas condutas possíveis - é proibido matar e é permitido matar em legítima defesa -, por óbvio que a conduta proibitiva é a regra; e a conduta permissiva, a exceção.

Na peça, o Tribunal ao absolver o comerciante reconheceu a legítima defesa putativa. Contudo, o fundamento da decisão foi que o Tribunal entendeu que a regra é "quem tem menos sempre ameaça quem tem mais":

$\mathrm{O}$ comerciante não pertencia à mesma classe do carregador, de quem só poderia pensar o pior. $\mathrm{O}$ comerciante jamais poderia acreditar em qualquer gesto de camaradagem por parte do carregador, [...] o bom senso lhe dizia que sobre ele pesavam as mais graves ameaças, [...]. O acusado, portanto, agiu em legítima defesa tanto no caso de ter sido realmente ameaçado quanto no caso de apenas sentir-se ameaçado (Brecht, 1990, p. 160).

O fundamento não é jurídico, é ideológico. Usa-se a previsão legal da exceção para não punir um criminoso. Reveste o injusto com o manto do Direito. 
Ora, na peça, o reconhecimento da legítima defesa putativa é baseado na crença de um medo oriundo das diferenças de classe social. Zygmunt Bauman, ao discorrer sobre o medo, afirma que é um sentimento conhecido por toda criatura viva, que ao se defrontar com uma ameaça real possui duas alternativas: a fuga ou a agressão. Os seres humanos, no entanto, conhecem outra espécie de ameaça, que não é real, é imaginária, e gera o que ele chamou de medo de segundo grau ou derivado, proveniente da percepção do mundo, experiências e comportamentos (2008, p. 9).

Brecht expõe de forma explícita a ideologia da luta de classes, narra o temor entre o comerciante e o cule, em que cada um reconhece no outro uma ameaça imaginária sustentada numa ideologia, portanto um medo de segundo grau. Fato é que o cule jamais ameaçou o comerciante. Entretanto, o Tribunal admitiu a existência dessa ameaça imaginária para absolvê-lo.

Surpreende como esses medos imaginários - chamados de segundo grau por Bauman - servem de justificativa para os mais diversos e variados atos. Vejamos um exemplo: um jovem motorista atropela outro jovem, um ciclista, no início de uma manhã de domingo. Com o impacto do acidente, o braço do ciclista fica preso ao carro e mesmo assim o atropelador segue seu caminho com o braço dentro do carro até encontrar um rio, onde o descarta, jogando-o fora como se fosse lixo (e como se fosse aceitável jogar lixo no rio). Como esse motorista justifica a sua conduta? Por que não socorreu a vítima? A resposta veiculada na imprensa é que deixou de agir por causa da multidão, supôs que seria linchado ${ }^{22}$. Mais do que a utilização do argumento, espanta a sua aceitação, a naturalidade da compreensão da justificativa de que não quis atropelar, que todos os fatos ocorridos após o atropelamento se deram para proteger sua própria vida. É uma justificativa da conduta anormal. Faz-se da exceção, regra²3.

\footnotetext{
${ }^{22}$ O fato narrado ocorreu em 10 de março de 2013. Na ocasião, a imprensa noticiou: "O advogado do motorista [...], de 22 anos, que atropelou o ciclista neste domingo, disse que seu cliente não prestou socorro à vítima porque temeu a reação de pessoas no local do acidente." (Disponível em: <http://g1.globo.com/sao-paulo/noticia/2013/o3/ciclistaatropelado-na-paulista-disse-mae-que-estava-na-ciclofaixa.html >. Acesso: 29 jan. 2015). Em 3 de junho de 2014, o motorista foi condenado por lesão corporal culposa a seis anos de prisão no regime semiaberto, podendo aguardar em liberdade até o julgamento da apelação. (Disponível em: <http://www1.folha.uol.com.br/cotidiano/2014/o6/1464553juiz-condena-motorista-que-atropelou-ciclista-na-av-paulista.shtml>. Acesso: 29 jan. 2015).

${ }^{23}$ Nas palavras do cancioneiro Zé Ramalho, em Admirável gado novo:
} 


\section{PARA CONCLUIR}

O diálogo entre Direito e Literatura amplia a compreensão do fenômeno jurídico, pois capta a ocorrência do Direito fora do âmbito dos poderes do Estado. No estudo do texto de Brecht, vimos temas como princípios de oralidade e publicidade do processo, direito a ter nome, responsabilidade civil e excludente da responsabilidade penal. A análise comportou ainda traçar semelhanças entre julgamento e encenação e, também, um paralelo entre o texto literário e uma decisão judicial.

O texto de Brecht instiga o jurista a refletir sobre a aplicação da norma jurídica, alerta a respeito do abuso da regra e a injustiça da exceção e suscita o quanto de ideológico existe na interpretação e aplicação do direito, mesmo que revestido de racionalidade.

\section{REFERÊNCIAS}

BAUMAN, Zygmunt. Medo líquido. Rio de Janeiro: J. Zahar, 2008.

BETTI, Emilio. Interpretação da lei e dos atos jurídicos. São Paulo: Martins Fontes, 2007.

BRECHT, Bertolt. Teatro completo. 2. ed. Rio de Janeiro: Paz e Terra, 1990. v. 4. p. 129-160.

CANETTI, Elias. Massa e poder. São Paulo: Comp. das Letras, 1995.

CARNELUTTI, Francesco. As misérias do processo penal. São Paulo: Conan, 1995.

DWORKIN, Ronald. Domínio da vida: aborto, eutanásia e liberdades individuais. São Paulo: Martins Fontes, 2009.

FOUCAULT, Michel. Microfísica do poder. 12. ed. Rio de Janeiro: Graal, 1996.

HORN, Norbert. Introdução à ciência do direito e à filosofia jurídica. Porto Alegre: Sergio Antonio Fabris Editor, 2005.

NERY, Rosa Maria de Andrade. Noções preliminares de direito civil. São Paulo: Revista dos Tribunais, 2002.

PONTES DE MIRANDA. Tratado de direito privado: parte especial. São Paulo: Revista dos Tribunais, 2012. t. 7.

SARLET, Ingo Wolfgang. A eficácia dos direitos fundamentais: uma teoria dos direitos fundamentais na perspectiva constitucional. 10. ed. Porto Alegre: Livraria do Advogado, 2011.

"Lá fora faz um tempo confortável

A vigilância cuida do normal

Os automóveis ouvem a notícia

Os homens a publicam no jornal" 
SILVA, Joana Maria Madeira de Aguiar e. Para uma teoria hermenêutica da justiça: repercussões jusliterárias no eixo problemático das fontes e da interpretação jurídicas. Tese (Doutorado em Direito)-Universidade do Minho, Minho, 2009. 412 f. Disponível em: <HTTP://hdl.handle.net/1822/9058>. Acesso em: 5 abr. 2015.

SILVA, Oscar Joseph de Plácido e. Vocabulário jurídico. 2. ed. Rio de Janeiro: Forense, 2004.

STRECK, Lenio. Tribunal do júri: símbolos e rituais. 4. ed. Porto Alegre: Livraria do Advogado, 2001.

TOLEDO, Francisco de Assis. Princípios básicos de direito penal. 4. ed. São Paulo: Saraiva, 1991.

Submetido: 29/01/15

Aceito: 25/04/15 